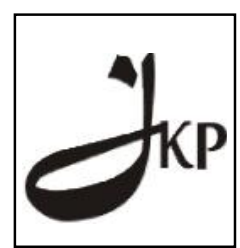

Jurnal Konseling dan Pendidikan

ISSN Cetak: 2337-6740 - ISSN Online: 2337-6880

http://jurnal.konselingindonesia.com

Volume 1 Nomor 2, Juni 2013, HIm 121-135

Info Artikel:

Diterima 03/04/2013

Direvisi 15/06/2013

Dipublikasikan 30/06/2013

Ikatan Konselor Indonesia (IKI)

\title{
Pengembangan Modul Bimbingan dan Konseling untuk Pencegahan Penyalahgunaan Narkoba di Sekolah
}

\author{
Rani Mega Putri ${ }^{1}$, Neviyarni S. ${ }^{2}$, Daharnis ${ }^{3}$ \\ ${ }^{123}$ Fakultas Ilmu Pendidikan, Universitas Negeri Padang
}

\begin{abstract}
The problem of drug abuse has penetrated up to the world of education, including SMP. Many ways that could be used by guidance and counseling teachers or counselors to enhance students' understanding of the dangers of drug abuse, one of them by using the media as an exciting learning modules. Module was one of tools that addresses learning about a subject systematically arranged and sequentially to facilitate students achieve and master a targeted competencies along with guidelines for the use of teachers. This study aimed: (1) to formulate guidance and counseling module for drug abuse prevention in school-appropriate content to be used by guidance and counseling teacher or counselor, and (2) to describe the level of applicability formulation guidance and counseling module for drug abuse prevention in school by guidance and counseling teacher or counselor. This research was conducted using development research methods, with guided model development step ADDIE (Analyze, Design, Development, Implementation, and Evaluation). The subjects of the trial research were (1) the content expert, and (2) the target users of the product, was guidance and counseling teacher or counselor, who was taken by using purposive sampling method, in order to obtain test subjects research, namely 3 content experts, and 3 people guidance and counseling teacher or counselor. This study was conducted with a limited research product tested and the data was analyzed descriptively. The results of the research showed that: (1) guidance and counseling module to prevent drug abuse, as a content was very feasible for used by students and guidance and counseling teachers or counselors in implementation of service, (2) the level of guidance module and counseling applicability to prevent of drug abuse rated very high for used by students. Based on these results of the research, generally, it could be concluded that the research products produced were feasible and could be used to help students in the context of prevention of drug abuse in schools. Finally the research product was highly recommended to be introduced and used by guidance and counseling teacher or counselor at school in SMP.
\end{abstract}

Keyword: Module, Guidance and Counseling, Drug Abuse Prevention

Copyright (C) 2013 IICE - Multikarya Kons (Padang - Indonesia) dan IKI - Ikatan Konselor Indonesia - All Rights Reserved Indonesian Institute for Counseling and Education (IICE) Multikarya Kons

\section{PENDAHULUAN}

Sekolah sebagai lembaga pendidikan formal memegang peranan dan bertanggung jawab dalam menunjang keberhasilan siswa untuk menjalankan tugas perkembangannya. Sekolah diharapkan dapat menyediakan program pembelajaran yang menarik, menyenangkan, menantang, membangun motivasi, dan memberi kesempatan kepada

\footnotetext{
${ }^{1}$ rani@konselor.org

3 daharnis@konselor.org
} 
siswa untuk melakukan kegiatan yang positif. Hal ini sesuai dengan Undang-Undang Nomor 20 Tahun 2003 tentang Sistem Pendidikan Nasional pasal 1 butir 1 yang menyebutkan bahwa:

Pendidikan adalah usaha sadar dan terencana untuk mewujudkan suasana belajar dan proses pembelajaran agar peserta didik secara aktif mengembangkan potensi dirinya untuk memiliki kekuatan spiritual keagamaan, pengendalian diri, kepribadian, kecerdasan, akhlak mulia, serta keterampilan yang diperlukan dirinya, masyarakat, bangsa dan negara.

Untuk menghasilkan pendidikan yang bermutu, maka penyelenggaraan pendidikan harus dilaksanakan dengan memperhatikan dan memperbaiki proses pendidikan yang diterapkan oleh penyelenggara pendidikan. Proses pembelajaran diharapkan mampu memfasilitasi siswa agar dapat mencapai aktualisasi diri sesuai dengan fungsi pendidikan yang tertuang pada Undang-Undang Sistem Pendidikan Nasional No. 20 Tahun 2003 Bab II Pasal 3 yaitu:

Pendidikan nasional berfungsi mengembangkan kemampuan dan membentuk watak serta peradaban bangsa yang bermartabat dalam rangka mencerdaskan kehidupan bangsa, bertujuan untuk berkembangnya potensi peserta didik agar menjadi manusia yang beriman dan bertakwa kepada Tuhan Yang Maha Esa, berakhlak mulia, sehat, berilmu, cakap, kreatif, mandiri, dan menjadi warga negara yang demokratis serta bertanggung jawab.

Hal tersebut dapat dimaknai bahwa pendidikan di sekolah selain bertanggung jawab terhadap dikuasainya pengetahuan dan keterampilan tertentu bagi siswanya, juga bertanggung jawab membentuk siswa menjadi individu yang beriman, bertaqwa, dan berakhlak mulia. Siswa yang beriman, bertaqwa dan berakhlak mulia memiliki indikator-indikator perilaku yang sesuai dengan nilai-nilai budaya yang luhur, norma-norma yang berlaku, yaitu sesuai dengan nilai-nilai ajaran agama yang diyakininya. Perilaku-perilaku yang demikian dapat berupa perilaku konstruktif yang tidak merusak diri sendiri dan lingkungan seperti jauh dari perilaku-perilaku menyakiti diri, lari dari kehidupan dan keluarga, terlibat pergaulan bebas, merokok, mengkonsumsi alkohol, serta menggunakan narkoba.

Dalam rangka mengembangkan fungsi tersebut diperlukan peran pendidik. Menurut Undang-Undang Sistem Pendidikan Nasional No. 20 Tahun 2003 Bab I Pasal 1 ayat 6, pendidik adalah tenaga kependidikan yang berkualifikasi sebagai guru, dosen, konselor, pamong belajar, widyaiswara, tutor, instruktur, fasilitator, dan sebutan lain yang sesuai dengan kekhususannya, serta berpartisipasi dalam menyelenggarakan pendidikan. Guru bimbingan dan konseling (selanjutnya disebut guru BK) atau konselor merupakan salah satu tenaga kependidikan. Dengan kata lain Bimbingan dan Konseling (selanjutnya disebut BK) terdapat dalam kurikulum pendidikan nasional. BK merupakan upaya pemberian bantuan melalui layanan konseling kepada siswa agar siswa tersebut mampu mengembangkan dirinya secara optimal untuk memiliki kekuatan spiritual keagamaan, pengendalian diri, kepribadian, kecerdasan, akhlak mulia, serta keterampilan yang diperlukan dirinya, masyarakat, bangsa dan negara seperti yang tertera pada hakikat pendidikan menurut Undang-Undang Sistem Pendidikan Nasional No. 20 Tahun 2003 Bab I Pasal 1.

Melalui pelayanan BK diharapkan siswa mampu mengatasi permasalahan yang dialaminya, hal ini seperti yang diungkapkan oleh BSNP (2006: 4) yaitu:

Pelayanan konseling memfasilitasi pengembangan peserta didik, secara individual, kelompok dan atau klasikal, sesuai dengan kebutuhan, potensi, bakat, minat, perkembangan, kondisi, serta peluangpeluang yang dimiliki. Pelayanan ini juga membantu mengatasi kelemahan dan hambatan serta masalah yang dihadapi peserta didik.

Hal tersebut mengandung makna bahwa guru BK atau konselor harus mengerti dan memahami siswa, baik itu bakat, minat, potensi, maupun perkembangannya sehingga memberikan peluang bagi guru BK atau konselor untuk membantu peserta didik mengatasi kelemahan, hambatan, serta masalah yang dialaminya. Pemberian bantuan tersebut dapat berupa pelayanan yang dilakukan secara perorangan, kelompok, maupun klasikal dengan 
memanfaatkan media pembelajaran. Salah satu media yang dapat digunakan oleh guru BK atau konselor dalam memberikan pelayanan konseling adalah modul.

Mulyasa (2004: 43) menyatakan bahwa modul adalah suatu proses pembelajaran mengenai suatu satuan kompetensi tertentu yang disusun secara sistematis, operasional dan terarah yang digunakan oleh peserta didik dan disertai dengan pedoman penggunaannya untuk guru. Senada dengan pendapat tersebut, Sidek Mohd Noah \& Jamaludin Ahmad (dalam Ahmad, 2007:134) menyatakan bahwa modul merupakan suatu paket pembelajaran yang membahas suatu topik tertentu secara sistematis dan berurutan untuk memudahkan siswa belajar mandiri dalam mencapai dan menguasai suatu unit topik pembelajaran dengan mudah dan tepat sasaran. Jadi, modul adalah sebuah media yang disusun secara sistematis menurut kaidah penulisan modul, yang membahas suatu topik dan dapat digunakan oleh siswa secara mandiri.

Dengan memanfaatkan modul, diharapkan siswa mampu untuk mandiri dan dapat mengembangkan potensinya secara optimal sesuai dengan tujuan konseling yaitu memandirikan klien. Suryosubroto (1983:12) menyatakan bahwa:

Dengan menggunakan modul, siswa dapat belajar sendiri tanpa tergantung pada guru, siswa dapat belajar tanpa terikat oleh tempat dan waktu, siswa juga dapat belajar sesuai dengan kecepatan masing-masing. Modul dapat memupuk sifat dinamis dan aktif karena siswa dituntun memecahkan masalah-masalah dan penemuanpenemuan

Lebih lanjut dijelaskan bahwa modul dapat dilengkapi dengan kegiatan-kegiatan instruksional, seperti membaca buku, melakukan percobaan, belajar dari internet dan lain-lain, sehingga siswa juga dituntun untuk belajar dari sumber-sumber yang relevan (Suryosubroto, 1983: 22). Nasution (1988: 67) menjelaskan keuntungan pembelajaran dengan modul adalah sebagai berikut:

1. memberikan feedback atau umpan balik yang segera dan terus-menerus.

2. dapat disesuaikan dengan kemampuan anak secara individual dengan memberikan keluwesan tentang kecepatan mempelajarinya.

3. memberikan secara khusus remedial untuk membantu anak mengatasi kekurangannya.

4. membuka kemungkinan untuk melakukan tes formatif.

Sedangkan menurut Santyasa (2009: 11) salah satu keuntungan yang diperoleh dari pembelajaran dengan menggunakan modul yaitu meningkatkan motivasi siswa, karena materinya dibatasi dengan jelas dan sesuai dengan kondisi di lapangan. Dengan menggunakan modul yang dirancang dengan baik mengikuti kaidah penyusunan modul, siswa dapat memperoleh pemahaman dan pengetahuan baru untuk menciptakan pandangan, wawasan, keterampilan, nilai dan sikap yang sesuai dengan tujuan hidup.

Prayitno (2009: 26) menyatakan bahwa "pelayanan konseling tertuju kepada kondisi pribadi yang mandiri, sukses dan berkehidupan efektif dalam kesehariannya". Jika dilihat dari tujuan pelayanan konseling untuk memandirikan klien, maka sistem belajar dengan menggunakan modul adalah salah satu cara yang diharapkan dapat memandirikan siswa dalam proses pembelajaran.

Dari hasil wawancara dengan beberapa orang guru BK atau konselor yang sedang melanjutkan pendidikan di Program Studi Bimbingan dan Konseling Program Pascasarjana Fakultas Ilmu Pendidikan Universitas Negeri Padang pada tanggal 07 Mei 2012, diketahui bahwa guru BK atau konselor tidak memiliki modul yang relevan untuk dijadikan bahan dalam memberikan layanan konseling. Guru BK atau konselor juga tidak dapat merumuskan bentuk modul yang sesuai dengan kaidah-kaidahnya, serta menganggap modul tidak penting karena menambah kerja guru BK atau konselor dan proses pembuatannya berbelit-belit. Hal ini membuat peneliti merasa tertarik untuk mengembangkan modul yang dapat membantu guru BK atau konselor dalam memberikan layanan konseling kepada siswanya.

Mencermati permasalahan siswa yang dapat diupayakan pencegahan dan pengentasannya oleh guru BK atau konselor melalui pelayanan konseling, nampaknya merokok dan mengkonsumsi alkohol adalah permasalahan yang banyak terjadi di sekolah. Padahal, rokok dan alkohol adalah gerbang awal untuk masuk pada penyalahgunaan narkoba yang lebih berat, tetapi layanan yang dilakukan oleh guru BK atau konselor untuk mencegah hal tersebut masih minim.

Fenomena di lapangan menunjukkan bahwa banyak terjadi kasus penyalahgunaan narkoba yang dilakukan oleh pelajar. Aziz (dalam tempo.co.id: diakses tanggal 23 April 2012) menuliskan bahwa salah seorang siswa sekolah menengah pertama di Cianjur, Jawa Barat, mengikuti Ujian Nasional dalam tahanan Kepolisian Resor 
Cianjur, Senin, 23 April 2012 karena terjerat kasus narkoba dengan Pasal 111 ayat 1 Undang-Undang Nomor 35 tentang Narkotika karena kepemilikan ganja. Berikutnya, Ali (dalam antarabogor.com: diakses tanggal 30 Juni 2012) menuliskan bahwa peredaran narkoba di kalangan pelajar SMP dan SMA sudah sangat mengkhawatirkan.

Berdasarkan data yang didapat dari Direktorat Reserse Narkoba Polda Sumbar menunjukkan bahwa jumlah kasus narkoba yang dilakukan oleh pelajar pada tahun 2010 adalah 13 kasus. Pada tahun 2011 menjadi 12 kasus. Pada tahun 2012 ditemukan 9 kasus yang dilakukan pelajar. Sedangkan berdasarkan aspek umur, ditemukan 13 kasus pada tahun 2010 untuk umur tersangka 16-19 tahun. Kasus ini meningkat menjadi 36 kasus pada tahun 2011. Dan meningkat lagi menjadi 41 kasus untuk umur tersangka 16-19 tahun pada tahun 2012.

Data di atas menunjukkan bahwa adanya peluang remaja yang terlibat dalam penyalahgunaan narkoba akan terus meluas dan meningkat jumlahnya. Dengan meluasnya penyalahgunaan narkoba tersebut maka akan semakin besar efek negatif yang ditimbulkan baik bagi remaja itu sendiri, keluarga dan lingkungan sosialnya. Martono dan Satya (2006: 24-26) menyatakan bahwa penyalahgunaan narkoba dapat menimbulkan efek negatif yang pertama bagi diri sendiri, yaitu: (a) terganggunya fungsi otak dan perkembangan remaja, (b) intoksikasi (keracunan), (c) over dosis, (d) gejala putus zat, (e) ketergantungan, (f) gangguan perilaku/ mental-sosial, (g) gangguan kesehatan, (h) kendornya nilai-nilai, dan (i) keuangan dan hukum menjadi kacau. Efek negatif yang kedua adalah bagi keluarga yaitu suasana hidup nyaman dan tentram di dalam keluarga menjadi terganggu, orangtua menjadi malu, sedih, merasa bersalah dan marah karena memiliki anak pecandu, serta merasa putus asa karena masa depan anak menjadi tidak jelas. Efek negatif yang ketiga adalah bagi sekolah, yaitu narkoba dapat merusak disiplin dan motivasi yang sangat penting bagi proses belajar mengajar di kelas dan prestasi belajar menurun drastis. Penyalahguna narkoba juga berkaitan dengan kenakalan dan putus sekolah. Kemungkinan siswa penyalahguna narkoba membolos lebih besar daripada siswa lainnya. Efek negatif yang keempat yaitu bagi masyarakat, bangsa dan negara yang dapat menimbulkan kerugian karena masyarakatnya tidak produktif dan tingkat kejahatan meningkat.

Berkenaan dengan banyaknya kerugian yang bisa ditimbulkan oleh peredaran gelap dan penyalahgunaan narkoba seperti tersebut di atas, maka penyalahgunaan narkoba bisa menjadi bencana nasional, dan harus diantisipasi oleh semua kalangan termasuk oleh pendidik pada satuan pendidikan dasar dan menengah. Jika hal ini tidak mendapatkan penanganan yang baik maka akan menjadi ancaman bagi kelangsungan hidup bangsa, khususnya rusaknya generasi muda yang diharapkan sebagai penerus bangsa.

Padang, sebagai salah satu ibukota Provinsi yang sedang berkembang, bisa menjadi sasaran empuk bagi orang-orang yang tidak bertanggung jawab dalam peredaran dan penyalahgunaan narkoba. Termasuk peredaran narkoba di kalangan pelajar SMP. Hasil observasi yang penulis lakukan di lingkungan salah satu sekolah swasta kota Padang, banyak ditemui siswa laki-laki yang merokok. Tidak hanya siswa SMA, tetapi juga sudah merambah pada siswa SMP dan SD.

Berdasarkan studi pendahuluan yang dilakukan pada salah satu SMP swasta kota Padang diperoleh informasi bahwa banyak siswa sekolah tersebut yang merokok dan mengkonsumsi alkohol. Ada juga siswa yang menghirup lem. Informasi tersebut didapat dari hasil wawancara dengan beberapa orang guru dan siswa, data kasus siswa dari guru BK atau konselor, serta hasil observasi di lapangan. Rokok dalam hal ini dipandang sebagai pintu masuk penyalahgunaan narkoba lain yang lebih berbahaya, karena rokok mengandung tembakau yang memiliki zat aktif yang dapat menyebabkan ketergantungan seperti nikotin, karbon monoksida dan tar. Dalam mengentaskan permasalahan ini dan mencegah ke arah penyalahgunaan narkoba yang lebih berbahaya, guru BK atau konselor belum memberikan pelayanan yang maksimal. Hal ini terkendala oleh waktu pemberian layanan serta belum ada media yang dapat digunakan untuk melakukan pelayanan konseling. Oleh sebab itu penulis merasa tertarik untuk bisa mengembangkan media berupa modul pencegahan penyalahgunaan narkoba berdasarkan fenomena yang terjadi pada sekolah ini.

Berangkat dari hal tersebut dan mempertimbangkan uraian di atas, maka peneliti tertarik untuk mengembangkan modul pencegahan penyalahgunaan narkoba di sekolah untuk membantu guru BK atau konselor dalam memberikan pelayanan konseling. Peneliti sangat mengharapkan produk yang dikembangkan dalam penelitian ini dapat memperbaiki dan mengurangi beberapa kekurangan-kekurangan dalam praktik pelayanan BK di sekolah, terutama untuk pencegahan penyalahgunaan narkoba.

Sehubungan dengan permasalahan di atas, maka rumusan masalah pada penelitian ini adalah (1) apakah rumusan modul BK yang dikembangkan untuk pencegahan penyalahgunaan narkoba di sekolah layak secara isi 
untuk digunakan oleh guru BK atau konselor?, dan (2) apakah rumusan modul BK untuk pencegahan penyalahgunaan narkoba di sekolah yang dikembangkan dapat digunakan oleh guru BK atau konselor?.

Adapun tujuan yang hendak dicapai dengan penelitian ini adalah untuk merumuskan modul pencegahan penyalahgunaan narkoba di sekolah yang layak secara isi untuk digunakan oleh guru BK atau konselor dan untuk mendeskripsikan tingkat keterpakaian rumusan modul BK untuk pencegahan penyalahgunaan narkoba di sekolah oleh guru BK atau konselor.

\section{METODOLOGI}

Penelitian ini merupakan penelitian pengembangan (development research). Dalam penelitian ini dikembangkan sebuah modul bimbingan dan konseling yang diharapkan dapat menjawab permasalahan di lapangan terkait dengan fenomena penyalahgunaan narkoba yang terjadi di sekolah. Prosedur pengembangan yang diterapkan dalam penelitian ini mengikuti langkah-langkah pengembangan menurut model ADDIE yang meliputi tahapan Analysis, Design, Development, Implementation, dan Evaluation. Antara tahapan-tahapan tersebut memiliki keterkaitan, namun tidak menutup kemungkinan pengembangan selanjutnya di waktu yang akan datang jika produk yang dihasilkan perlu pengembangan lebih lanjut.

Dalam penelitian ini, kegiatan pengembangan produk yang dilakukan peneliti hanya sampai pada tahap uji kelompok kecil. Pertimbangan peneliti melakukan pengembangan produk hingga tahap uji kelompok kecil yaitu untuk menghasilkan prototype produk (modul) yang secara isi telah memenuhi kriteria hasil validasi para ahli dan dapat dipakai oleh guru BK atau konselor di sekolah.

Adapun teknik yang digunakan untuk menentukan subjek uji coba untuk ahli isi dan uji keterpakaian produk menggunakan purposive sampling. Teknik purposive sampling, merupakan cara penentuan atau pengambilan sampel secara acak didasarkan pada maksud atau tujuan penelitian yang telah ditetapkan sebelumnya (Yusuf, 2005b: 205). Alasan penggunaan purposive sampling sebagai teknik penentuan subjek uji coba yaitu penelitian ini hanya berfokus pada suatu masalah yaitu mengembangkan modul bimbingan dan konseling untuk pencegahan penyalahgunaan narkoba. Selain itu, penelitian ini tidak bermaksud membuat generalisasi penelitian sehingga teknik penentuan subjek uji coba dalam penelitian pengembangan ini dikelompokkan ke dalam non-probability sampling yaitu teknik pengambilan sampel yang tidak memberikan peluang/kesempatan sama bagi setiap unsur atau anggota populasi untuk dipilih menjadi sampel (Sugiyono, 2008: 122).

Berdasarkan pertimbangan tersebut, maka subjek uji coba dalam penelitian ini ditentukan sebagai berikut.

Tahap Validasi Produk

Validasi ahli melibatkan subjek uji coba sebagai ahli, terdiri dari 3 orang ahli. Ahli yang melakukan validasi yaitu, Prof. Dr. Mudjiran, M.S., Kons. (Dosen Jurusan Bimbingan dan Konseling UNP), Dr. Erizal Gani, M.Pd. (Dosen Jurusan Pendidikan Bahasa Indonesia UNP), dan Prof. Dr. Sayuti Syahara, M.S., AIFO (Ahli Ilmu Fisiologi Olahraga, Dosen Fakultas Ilmu Keolahragaan UNP).

\section{Tahap Uji Coba Produk}

Pada tahap uji perseorangan dan uji kelompok kecil, subjek uji coba dipilih dengan landasan pertimbangan tertentu sesuai dengan maksud, tujuan, atau kegunaan dari produk penelitian. Karakteristik dari subjek uji coba yang diinginkan sebagai sasaran pemakai produk yang melakukan uji keterbacaan adalah siswa kelas VII, dengan anggapan bahwa siswa SMP perlu dibekali dengan pengetahuan tentang pencegahan penyalahgunaan narkoba sedari dini, yaitu saat berada pada kelas VII. Selain siswa, yang menjadi subjek uji coba pemakai produk adalah guru BK atau konselor dengan latar belakang pendidikan S1 BK dan PPK. Dengan anggapan bahwa guru BK dengan latar belakang pendidikan S1 BK dan PPK sudah profesional dalam menyelenggarakan pelayanan konseling secara akademis dan praktik. Untuk uji coba perseorangan produk penelitian, peneliti melibatkan 1 orang guru BK atau konselor kelas VII SMP Kartika I-7 Padang, sedangkan uji coba kelompok kecil, peneliti melibatkan 3 orang guru BK atau konselor, yaitu 2 orang guru BK atau konselor dari SMP N 5 Padang dan 1 orang guru BK atau konselor SMP Laboratorium Pembangunan UNP. Pemilihan sekolah tersebut menjadi subjek uji coba dengan pertimbangan: (a) sekolah tersebut memiliki guru BK yang sesuai dengan kriteria yaitu S1 BK dan PPK, (b) sekolah tersebut berada di daerah keramaian dan pusat kota, (c) lingkungan sekolah tersebut berdekatan dengan lingkungan pendidikan yang lebih tinggi, dan (d) siswa memiliki latar belakang ekonomi yang beragam. 
Data yang dikumpulkan pada penelitian ini yaitu:

\section{Data Validasi Modul}

Peneliti mengumpulkan data dari ahli berkenaan dengan penilaian isi modul bimbingan dan konseling untuk pencegahan penyalahgunaan narkoba. Data isi produk diperoleh dari proses validasi oleh ahli.

\section{Data Keterpakaian Modul}

Pengumpulan data keterpakaian modul dilakukan pada guru BK atau konselor. Modul yang telah divalidasi oleh ahli, diuji coba perseorangan dan uji coba kelompok kecil pada guru BK atau konselor, kemudian dilakukan pengukuran dengan menggunakan angket untuk menilai produk.

Untuk keterbacaan isi modul, dilakukan uji coba kepada siswa dengan cara menandai isi yang tidak dipahami siswa. Hasil yang diperoleh menjadi pedoman bagi peneliti untuk menyesuaikan kalimat dan istilah sesuai dengan tingkat pemahaman bahasa siswa SMP.

Instrumen pengumpulan data dalam penelitian ini disesuaikan dengan karakteristik data dan subjek penelitian. Adapun instrumen pengumpulan data dalam penelitian ini yaitu kuesioner yang dikembangkan sendiri oleh peneliti.

Menurut Yusuf (2005a:252) "Kuesioner berasal dari bahasa latin, Questionnaire yang berarti suatu rangkaian pertanyaan yang berhubungan dengan objek yang dinilai dengan maksud untuk mendapatkan data atau informasi. Kuesioner sering juga disebut angket”. Penelitian ini menggunakan angket yang ditujukan kepada ahli untuk mengumpulkan data yang berkenaan dengan isi modul yang dikembangkan dan kepada guru BK atau konselor untuk mengumpulkan data keterpakaian modul.

Teknik analisis data yang digunakan adalah analisis deskriptif, yakni dengan mendeskripsikan distribusi skor masing-masing subjek uji coba validitas dan keterpakaian modul BK untuk pencegahan penyalahgunaan narkoba di sekolah. Untuk mengetahui lebih jauh mengenai hasil penilaian berkenaan dengan produk penelitian yang dikembangkan, maka dilakukan uji statistik untuk mengetahui apakah terdapat keselarasan penilaian baik antar masing-masing validator berkenaan dengan isi modul dan antar masing-masing guru BK atau konselor terhadap keterpakaian modul. Karena jumlah responden sebagai subyek penelitian kurang dari 30, maka digunakan analisis statistic non parametric, dengan uji statistik yang digunakan adalah Uji Koefisien Konkordansi Kendall (W).

\section{HASIL DAN PEMBAHASAN}

Penyajian hasil pengembangan mempedomani pola ADDIE yaitu (1) tahap analisis, (2) tahap desain, (3) tahap pengembangan, (4) tahap implementasi, dan (5) tahap evaluasi.

Tahap Analisis

\section{Pelaksanaan Layanan BK di Sekolah}

Pelaksanaan layanan BK di sekolah terbagi menjadi tiga format, yaitu: format klasikal, kelompok dan individual. Untuk dapat mengembangkan kehidupan sehari-hari siswa yang efektif, pelayanan BK yang dilaksanakan tersebut dapat dilakukan secara terjadwal dan insidental. Pelayanan BK tersebut dilaksanakan melalui 10 (sepuluh) jenis layanan, yaitu: layanan orientasi, informasi, penguasaan konten, penempatan dan penyaluran, konseling perorangan, bimbingan kelompok, konseling kelompok, konsultasi, mediasi, dan advokasi. Pelayanan tersebut juga dilaksanakan melalui 6 (enam) kegiatan pendukung, yaitu aplikasi instrumentasi, himpunan data, konferensi kasus, kunjungan rumah, tampilan kepustakaan, dan alih tangan kasus. Pelaksanaan kegiatan layanan konseling di sekolah didasarkan pada pemilihan jenis layanan dan kegiatan pendukung yang mengacu kepada kebutuhan siswa di sekolah yang didapat melalui studi kebutuhan.

Mencermati pelaksanaan pelayanan BK di sekolah selama ini, ditemui kenyataan bahwa guru BK atau konselor mengalami kesulitan dalam mencari bahan/sumber yang relevan sebagai penunjang pemberian layanan. Materi layanan yang diberikan cenderung sama setiap tahunnya padahal kebutuhan siswa selalu bertambah sesuai dengan perkembangan zaman.

Berkenaan dengan pelayanan BK yang dalam pelaksanaannya masih minim bahan/sumber yang relevan sesungguhnya patut dibenahi. Guru BK atau konselor dituntut lebih aktif dan kreatif dalam mengembangkan maupun menciptakan strategi serta bahan layanan terkait dengan kebutuhan siswa, yang salah satunya melalui modul layanan. 


\section{Cara untuk Membantu Siswa Tercegah dari Penyalahgunaan Narkoba}

Penyalahgunaan narkoba belakangan ini tidak hanya dilakukan oleh orang-orang dewasa. Kasus penyalahgunaan narkoba sudah merambah sampai ke dunia pendidikan, tidak terkecuali siswa SMP. Penyalahgunaan narkoba terjadi dalam bentuk yang paling kecil bahayanya sampai yang paling besar. Berdasarkan observasi yang peneliti lakukan terhadap siswa SMP kota Padang, banyak ditemukan siswa yang merokok dan mengkonsumsi alkohol. Padahal, rokok dan alkohol merupakan gerbang menuju penyalahgunaan narkoba yang lebih berat. Tidak sedikit pula dari mereka yang menghisap lem, padahal lem juga termasuk salah satu inhalant (zat psiko-aktif) yang dapat membuat seseorang kecanduan.

Dalam kasus tersebut, maka guru BK atau konselor wajib mengupayakan pelayanan BK yang baik, sebab dengan pelayanan yang baik dan komprehensif siswa akan terbantu untuk mencapai kehidupan sehari-harinya yang efektif. Tindakan preventif yang selama ini dilakukan oleh guru BK atau konselor adalah menghadirkan narasumber untuk memberikan penyuluhan tentang pencegahan penyalahgunaan narkoba. Dengan hadirnya modul yang peneliti kembangkan ini, diharapkan dapat membantu guru BK atau konselor dalam menyelenggarakan layanan konseling dan membantu siswa tercegah dari penyalahgunaan narkoba.

\section{Tahap Desain}

Berdasarkan hasil uraian yang dipaparkan pada tahap analisis, baik terkait dengan pelayanan BK di sekolah dan cara yang dilakukan untuk pencegahan penyalahgunaan narkoba tersebut, maka disusun desain awal modul pencegahan penyalahgunaan narkoba di sekolah.

Desain awal modul pencegahan penyalahgunaan narkoba diuraikan dalam dua bagian modul yaitu:

a. Narkoba

1) Apa itu narkoba?

2) Rokok

b. Mencegah penyalahgunaan narkoba

1) Asertif terhadap narkoba

2) Berpikir positif

3) Percaya diri.

Setelah menyelesaikan penyusunan desain awal modul pencegahan penyalahgunaan narkoba di sekolah, selanjutnya adalah menentukan keterlibatan pihak-pihak terkait dan rancangan penerapan produk. Dari kegiatan desain ini maka didapatkan wujud akhir desain awal produk yaitu modul pencegahan penyalahgunaan narkoba di sekolah. Selanjutnya wujud akhir desain awal produk ini diajukan untuk mendapatkan validasi oleh ahli.

\section{Tahap Pengembangan}

Tahap pengembangan ini dilakukan melalui dua jenis kegiatan yaitu pengembangan instrumen penelitian dan pengembangan produk penelitian, seperti diuraikan berikut ini.

\section{Pengembangan Instrumen Penelitian}

Pada tahapan ini dilakukan pengembangan terhadap instrumen penelitian yang akan digunakan dalam pengumpulan data. Instrumen tersebut yaitu (1) angket penilaian isi modul dalam rangka validasi isi oleh ahli, dan (2) angket keterpakaian modul untuk guru BK atau konselor.

Angket penilaian isi modul pengembangannya dilakukan oleh peneliti dengan melibatkan pembimbing I dan II melalui diskusi terfokus untuk menimbang aspek, redaksi kalimat setiap butir pernyataan, keefektifan susunan kalimat dan koreksi terhadap bentuk angket yang digunakan. Sementara angket keterpakaian modul selain melibatkan pembimbing I dan II juga melibatkan 3 (tiga) orang ahli dengan mengikuti prosedur sebagai berikut.

\section{Prosedur pengembangan}

\section{a) Identifikasi aspek alat ukur}

Pada tahapan ini dilakukan pengkajian, pemilihan dan penyeleksian aspek-aspek yang hendak diukur dalam penggunaan modul untuk pencegahan penyalahgunaan narkoba yaitu: (1) menentukan aspek yang hendak diukur. Dalam hal ini aspek keterpakaian produk, (2) menyusun redaksi kalimat pernyataan instrumen, (3) pemilihan jenis skala penilaian yang digunakan. Dalam hal ini digunakan Skala Likert, (4) teknik penskoran, dan (5) penyusunan petunjuk pengisian instrumen.

b) Menimbang pernyataan alat ukur

Untuk mengukur validitas konstruk instrumen keterpakaian yang disusun, peneliti melakukan expert judgement, yaitu meminta bantuan ahli memeriksa isi instrumen untuk mengetahui apakah instrumen yang 
digunakan dalam penelitian ini sudah dapat mengukur apa yang ingin diukur. Kegiatan penimbangan ini berorientasi pada aspek, redaksi kalimat setiap butir pernyataan, keefektifan susunan kalimat dan koreksi terhadap bentuk angket yang digunakan. Berdasarkan hasil judgement terhadap angket keterpakaian dihasilkan kesamaan pendapat dan beberapa perbaikan, utamanya berkaitan dengan penyempurnaan katakata dan bahasa yang digunakan.

c) Menyempurnakan alat ukur dan melakukan uji coba

Perbaikan instrumen dilakukan dengan menyempurnakan redaksi kata-kata dalam setiap item/pernyataan. Setelah penyempurnaan alat ukur dilakukan uji keterbacaan kepada 3 (tiga) orang guru BK atau konselor. Berdasarkan hasil uji keterbacaan ditemukan bahwa ternyata semua guru BK atau konselor memahami pernyataan dan alternatif yang tertuang pada instrumen penelitian.

\section{1) Bentuk akhir alat ukur}

Instrumen (angket keterpakaian) ini pada akhirnya terdiri dari 15 item/pernyataan yang mencakup tiga aspek keterpakaian yang diukur. Tiap aspek yang ada terdiri dari tiga sampai dengan tujuh item/pernyataan. Hal ini tergantung pada bobot materi yang diungkapkan pada setiap aspek. Untuk alternatif jawaban dan bobot skor dalam instrumen yang diberi tanda centang $(\sqrt{ })$ oleh responden penelitian terdiri dari 5 (lima) alternatif jawaban dan skor, yaitu: (a) sangat tinggi, dengan skor 5, (b) tinggi, dengan skor 4, (c) cukup tinggi, dengan skor 3, (d) rendah, dengan skor 2, dan (e) sangat rendah, dengan skor 1. Wujud akhir instrumen/angket keterpakaian ini secara lengkap disajikan pada Lampiran 1 dan 2 penelitian ini.

\section{a. Pengembangan Produk Awal}

Bagian ini menyajikan data yang diperoleh peneliti dari para ahli mengenai kualitas isi modul yang disusun. Data ini mengungkapkan tingkat kelayakan secara isi modul pencegahan penyalahgunaan narkoba sehingga dapat dipakai oleh siswa dan dapat dioperasionalisasikan oleh guru BK atau konselor di sekolah. Data isi/konstruk dihimpun berdasarkan angket penilaian yang diberikan oleh 3 (tiga) orang ahli.

Pengumpulan data untuk tahap validasi ahli dilakukan pada tanggal $1-24$ April 2013. Selain menggunakan angket, dalam proses pengumpulan data juga melakukan konsultasi dan diskusi berkenaan dengan rumusan modul yang dikembangkan. Data yang diperoleh dari para ahli berupa data dalam bentuk skor dan komentar beserta saran berkenaan dengan rumusan modul yang disusun. Adapun aspek-aspek penilaian ahli isi mencakup:

1) tampilan/daya tarik modul,

2) langkah-langkah pelaksanaan modul,

3) peran guru $\mathrm{BK}$ atau konselor,

4) materi modul,

5) pemakaian bahasa.

Hasil penelitian dari semua aspek dikumpulkan dan digunakan sebagai acuan dalam melakukan revisi terhadap produk yang disusun, sehingga diperoleh rumusan modul yang layak secara isi/ konstruk untuk digunakan oleh siswa dan dioperasionalkan oleh praktisi di lapangan. Angket validasi ahli ini dibuat dalam bentuk skala likert, seluruh item penilaian berbentuk positif, dengan pembagian kategori pada alternatif pilihan sebagai berikut; skor 1 sangat tidak layak, skor 2 tidak layak, skor 3 cukup layak, skor 4 layak dan skor 5 sangat layak. Dengan demikian dapat dipahami jika respon yang diberikan dengan skor 3 berarti responden belum memberikan keputusan pasti mengenai layak atau tidak, jika respon yang diberikan dengan skor 1 atau 2 berarti responden menyatakan secara umum rumusan yang disusun belum mencapai taraf kelayakan secara isi/konstruk, dan jika respon yang diberikan dengan skor 4 atau 5 berarti responden menyatakan secara umum rumusan yang disusun telah mencapai taraf kelayakan secara isi/konstruk. 
Hasil validasi ahli berkenaan dengan penilaian terhadap isi/konstruk modul pencegahan penyalahgunaan narkoba di sekolah selanjutnya disajikan dalam Tabel 1 berikut.

Tabel 1.

\section{Data Hasil Validasi Ahli Isi/ Konstruk}

\begin{tabular}{|c|c|c|c|c|c|c|c|}
\hline \multirow[t]{2}{*}{ No } & \multirow[t]{2}{*}{ Aspek } & \multicolumn{3}{|c|}{ Skor Ahli } & \multirow[t]{2}{*}{ Rata-rata } & \multirow[t]{2}{*}{$\%$} & \multirow[t]{2}{*}{ Ket. } \\
\hline & & $\mathbf{A}$ & $\mathbf{B}$ & $\mathbf{C}$ & & & \\
\hline 1 & Tampilan/ daya tarik modul & 21 & 20 & 21 & 20,67 & 82,67 & Sangat Layak \\
\hline 2 & $\begin{array}{l}\text { Langkah-langkah pelaksanaan } \\
\text { modul }\end{array}$ & 9 & 8 & 10 & 9 & 90,00 & Sangat Layak \\
\hline 3 & Peran guru BK atau Konselor & 8 & 8 & 9 & 8,33 & 83,33 & Sangat Layak \\
\hline 4 & Materi modul & 39 & 38 & 42 & 39,67 & 88,15 & Sangat Layak \\
\hline 5 & Pemakaian bahasa & 27 & 28 & 30 & 28,33 & 94,44 & Sangat Layak \\
\hline \multicolumn{5}{|c|}{ Rata-rata } & 21,20 & 87,72 & Sangat Layak \\
\hline
\end{tabular}

Berdasarkan Tabel 1 dapat diketahui bahwa secara keseluruhan penilaian yang diberikan oleh para ahli terhadap modul adalah sangat layak dengan persentase 87,72. Artinya, ahli memberikan penilaian yang positif terhadap modul yang dikembangkan, baik dari segi tampilan/daya tarik modul, langkah-langkah pelaksanaan modul, peran guru BK atau konselor, materi modul, serta pemakaian bahasa. Modul dinilai dapat diimplementasikan oleh guru BK atau konselor dalam memberikan layanan konseling dan dapat dipakai oleh siswa di SMP untuk pencegahan penyalahgunaan narkoba.

Untuk mengetahui lebih jauh mengenai hasil penilaian berkenaan dengan produk penelitian yang dikembangkan, maka dilakukan uji statistik untuk mengetahui apakah terdapat keselarasan penilaian antar masing-masing validator berkenaan dengan isi modul. Analisis yang peneliti gunakan adalah Uji Konkordansi Kendall.Jumlah N sebagai item yang dinilai yaitu sebanyak 24. Jika N lebih besar dari 7, dilakukan uji signifikansi $W$ dengan menggunakan pendekatan distribusi chi-square $\left(\chi^{2}\right)$ dengan $\mathrm{db}=\mathrm{N}-1$ (Siegel, 1997: 292). Untuk itu perlu ditemukan harga $\chi^{2}$ dengan memanfaatkan hasil perhitungan SPSS Version 16.

Berdasarkan perhitungan tersebut, diketahui bahwa harga chi-square hitung > harga chi-square tabel $(37,778>35,17)$ pada $\alpha=0,05(\mathrm{db}=\mathrm{N}-1)$. Hal ini berarti bahwa terdapat keselarasan penilaian antar ahli terhadap produk yang dinilai. Harga W mengindikasikan penilaian yang diberikan oleh para ahli berada pada tingkat hubungan yang kuat. Hal ini dapat dibuktikan dengan melihat harga W sebesar 0,548.

Berdasarkan uraian tersebut, maka penilaian yang diberikan oleh para ahli menunjukkan bahwa desain modul yang dikembangkan dinyatakan layak secara isi/konstruk untuk diterapkan oleh guru BK atau konselor di sekolah. Dengan demikian dapat disimpulkan bahwa para ahli sepakat mengenai kelayakan isi/konstruk modul yang disusun. Dari hasil uji statistik jika dikaitkan dengan persentase keseluruhan 87,72\% yang berada pada kategori penilaian sangat layak, dapat dimaknai bahwa terdapat keselarasan/kesesuaian penilaian yang positif dari ketiga ahli terhadap produk penelitian yang dikembangkan.

\section{b. Revisi Produk}

Berdasarkan hasil analisis pada tahap validasi ahli maka dilakukan revisi produk. Kegiatan revisi produk bertujuan untuk melakukan perbaikan guna penyempurnaan modul yang telah disusun berdasarkan masukan dari para ahli. Adapun masukan para ahli secara umum disajikan sebagai berikut.

1) Bahasa/istilah yang digunakan harus sesuai dengan tingkat perkembangan siswa yang akan memakai produk. Selanjutnya beberapa kesalahan dalam penulisan modul harus dihindari agar tidak menimbulkan salah tafsir terhadap maksud dan tujuan modul.

2) Evaluasi yang digunakan pada modul harus sesuai dengan indikator yang telah ditetapkan sebelumnya. Secara umum evaluasi yang disusun harus bisa mengungkap pemahaman dan usaha siswa dalam mencegah penyalahgunaan narkoba.

3) Gambar yang digunakan sebagai isi modul pencegahan penyalahgunaan narkoba harus sesuai dengan karakteristik siswa SMP sebagai pemakai produk. 
4) Background yang digunakan sebaiknya tidak dipenuhi oleh gambar bunga karena akan menyebabkan modul yang dibuat terkesan hanya untuk siswa perempuan.

5) Setiap bagian Bab sebaiknya menggunakan halaman pembatas.

6) Modul yang dikembangkan dilengkapi dengan panduan penggunaan modul.

Berdasarkan uraian tersebut, maka dilakukan perbaikan terhadap modul untuk bisa diimplementasikan pada tahap uji coba pada guru BK atau konselor untuk melihat keterpakaian produk.

\section{Tahap Implementasi}

\section{a. Uji Kelompok Kecil}

Data yang dipaparkan pada bagian ini merupakan kelanjutan dari rangkaian penelitian dan pengembangan produk setelah proses pengembangan, uji perseorangan dan revisi produk dilakukan. Subjek uji kelompok kecil yaitu diterapkan kepada 3 (tiga) orang guru BK atau konselor dengan tujuan memberikan penilaian mengenai aspek keterpakaian terhadap modul yang dikembangkan. Para guru BK atau konselor mengisi angket dan saran atau komentar berkenaan dengan produk penelitian yang dikembangkan berdasarkan pengalaman memanfaatkan modul dalam layanan konseling.

\section{1) Perencanaan}

Pada bagian ini dilakukan perencanaan pelaksanaan uji kelompok kecil produk yang akan dipraktikkan oleh guru BK atau konselor. Aspek yang menjadi fokus dari tahap perencanaan ini meliputi hal-hal seperti yang dikemukakan di bawah ini:

a) Membagikan modul yang telah divalidasi oleh ahli kepada para guru BK atau konselor. Pembagian modul dimaksudkan untuk memberikan kesempatan kepada para guru BK atau konselor untuk mempelajari dengan seksama rumusan yang termuat dalam produk. Mengurus persyaratan administrasi berupa surat izin penelitian dari Dinas Pendidikan Kota Padang.

b) Menyampaikan surat izin penelitian kepada pihak sekolah yang dijadikan tempat pengambilan data, yaitu SMP Negeri 5 Padang dan SMP Laboratorium Pembangunan UNP.

c) Melakukan diskusi terfokus terhadap arah implementasi produk yang akan diujicobakan. Hal-hal yang menjadi fokus kegiatan ini meliputi bagaimana guru BK atau konselor dapat melakukan langkah-langkah penggunaan modul seperti yang tertera pada modul dan panduannya.

d) Guru BK atau konselor mempraktikkan salah satu materi modul dalam layanan konseling.

e) Melakukan komunikasi kembali dengan para guru BK atau konselor terkait kesediaan waktu untuk pengambilan data penelitian.

\section{2) Pelaksanaan}

Berdasarkan perencanaan yang telah disusun dan disepakati bersama oleh peneliti dengan guru BK atau konselor, maka pada tahapan ini produk diimplementasikan dalam rangka uji kelompok kecil. Sasaran layanan yang diujicobakan yaitu siswa kelas VII yang dipilih oleh guru BK atau konselor. Sasaran layanan dalam hal ini siswa kelas VII diberi satu kali layanan dengan memanfaatkan modul yang dikembangkan.

\section{3) Analisis Hasil Pelaksanaan}

Berdasarkan hasil implementasi produk yang dilakukan para guru BK atau konselor, maka berikut dikemukakan temuan dari hasil penerapan modul BK untuk pencegahan penyalahgunaan narkoba di SMP. Data yang disajikan dalam kegiatan ini yaitu data yang berkenaan dengan respon guru BK atau konselor terhadap tingkat keterpakaian modul. Berikut deskripsi data hasil penilaian guru BK atau konselor terhadap keterpakaian modul. 


\begin{tabular}{llllllll}
\hline No & Aspek & \multicolumn{2}{l}{ Skor Guru BK } & \multicolumn{2}{c}{ Rata-rata } & $\%$ & \multicolumn{2}{c}{ Ket. } \\
\cline { 3 - 5 } & & A & B & C & & & Tinggi \\
$\mathbf{1}$ & Perencanaan & 11 & 11 & 12 & 11,3 & 75,5 & Sangat tinggi \\
$\mathbf{2}$ & Pelaksanaan & 31 & 32 & 34 & 32,3 & 92,3 & Sangat tinggi \\
\hline $\mathbf{3}$ & Evaluasi & 22 & 24 & 25 & 23,6 & 94,6 & Sangat tinggi \\
\hline
\end{tabular}

Tabel 2.

\section{Data Hasil Keterpakaian}

Berdasarkan Tabel 2 dapat diketahui bahwa secara keseluruhan penilaian yang diberikan oleh para guru BK atau konselor terhadap keterpakaian modul adalah sangat tinggi dengan persentase 87,53. Artinya, para guru BK atau konselor memberikan penilaian yang positif terhadap hadirnya modul sebagai media dalam memberikan layanan konseling. Guru BK atau konselor dapat menggunakan modul dengan baik yang dapat dilihat dari segi perencanaan, pelaksanaan, dan evaluasi yang berada pada kategori keterpakaian sangat tinggi.

Selanjutnya, untuk mengetahui lebih lanjut mengenai hasil penilaian berkenaan dengan produk penelitian yang dikembangkan, maka dilakukan uji statistik untuk mengetahui apakah terdapat keselarasan penilaian antar masing-masing guru BK atau konselor berkenaan dengan keterpakaian modul. Analisis yang peneliti gunakan adalah Uji Konkordansi Kendall.

Jumlah N sebagai aspek yang dinilai yaitu sebanyak 15. Untuk menentukan tingkat keselarasan penilaian ahli, ditempuh dengan menggunakan pendekatan distribusi chi-square dengan $\mathrm{db}=(\mathrm{N}-1)$.

Berdasarkan perhitungan di atas, diketahui bahwa harga chi-square hitung > harga chi-square tabel $(26,730>23,68)$ pada $\alpha=0,05(\mathrm{db}=\mathrm{N}-1)$. Hal ini berarti bahwa terdapat keselarasan penilaian antar guru BK atau konselor terhadap produk yang dinilai. Harga W mengindikasikan penilaian yang diberikan oleh para guru BK atau konselor berada pada tingkat hubungan yang kuat. Hal ini dapat dibuktikan dengan melihat harga W sebesar 0,636 sebagai tingkat hubungan yang sangat kuat dan bernilai positif.

Berdasarkan uraian tersebut, maka penilaian yang diberikan oleh guru BK atau konselor ditemukan bahwa desain modul yang dikembangkan dinyatakan dapat diterapkan oleh guru BK atau konselor di sekolah. Dengan demikian dapat disimpulkan bahwa ada kecocokan/keselarasan penilaian para guru BK atau konselor mengenai keterpakaian modul yang disusun. Dari hasil uji statistik jika dikaitkan dengan persentase keseluruhan 87,53\% yang berada pada kategori penilaian sangat tinggi, dapat dimaknai bahwa terdapat keselarasan/kesesuaian penilaian yang positif dari ketiga guru terhadap

\section{Tahap Evaluasi} produk penelitian yang dikembangkan.

Tahapan evaluasi merupakan tahapan yang bertujuan menilai secara keseluruhan aspek keterpakaian produk yang dikembangkan. Kegiatan evaluasi dalam tahapan ini, yaitu mendapatkan respon dari para guru BK atau konselor terkait upaya pengembangan dan keberadaan produk yang ditawarkan.

Respons dari guru BK atau konselor yang menjadi subjek penelitian pengembangan produk secara umum terungkap bahwa penggunaan modul BK untuk pencegahan penyalahgunaan narkoba di sekolah menunjukkan hal yang cukup positif. Ada tiga aspek yang dapat dicermati sebagai indikator ketercapaian, yaitu:

a. Tanggapan guru BK atau konselor terhadap upaya pengembangan modul pada prinsipnya adalah penting. Guru BK atau konselor menyambut dengan antusias modul yang ditawarkan sebagai bahan untuk melaksanakan layanan konseling dalam rangka pencegahan penyalahgunaan narkoba.

b. Dampak kehadiran produk pada prinsipnya dirasakan secara positif oleh guru BK atau konselor. Dengan kehadiran produk ini menambah strategi yang dapat digunakan oleh guru BK atau konselor untuk membantu siswa tercegah dari penyalahgunaan narkoba. 
c. Seluruh guru BK atau konselor yang dimintai keterangan terkait kemungkinan penerapan modul di sekolah jika dilihat dari kesiapan guru BK atau konselor dan prosedur pelaksanaannya menyatakan kesanggupan dalam melaksanakan kegiatan layanan.

Meskipun tanggapan yang diberikan oleh para guru BK atau konselor terkait upaya pengembangan produk secara umum menunjukkan hasil yang cukup memuaskan, namun ditemui juga respon guru BK atau konselor terkait kemungkinan kendala dalam mengimplementasikan modul. Kendala tersebut umumnya terkait dengan suasana yang berkembang pada proses layanan. Adapun kendala secara umum dirangkum sebagai berikut.

a. Waktu merupakan kendala utama bagi guru BK atau konselor untuk menerapkan modul dalam layanan konseling yang diberikan kepada siswa.

b. Kondisi insidental yang terjadi saat pemberian layanan menghambat penggunaan modul dalam layanan konseling yang dilakukan oleh guru BK atau konselor.

Respon guru BK atau konselor yang mengisyaratkan kendala ketika mempraktikkan produk oleh peneliti merupakan hal yang sangat berharga untuk membenahi produk.

Berdasarkan hasil temuan yang diperoleh dari tahapan evaluasi, maka dilakukan revisi produk dengan tujuan menyempurnakan produk agar lebih baik dari sebelumnya. Hal-hal yang menjadi inti revisi produk difokuskan pada komponen atau aspek yang termuat dalam modul yang diuraikan sebagai berikut.

\section{Waktu}

Merevisi pengaturan waktu pada tiap pokok bahasan modul agar disesuaikan dengan jam pembelajaran yang ada di sekolah, yaitu 1 jam pembelajaran 40 menit.

\section{Pemakaian Bahasa}

Revisi produk dilakukan dalam kaitannya dengan penggunaan tata bahasa yang sesuai dengan ejaan yang disempurnakan (EYD). Wujud akhir panduan setelah melalui proses revisi dapat dilihat pada lampiran.

\section{PEMBAHASAN}

\section{Modul Bimbingan dan Konseling untuk Pencegahan Penyalahgunaan Narkoba di Sekolah.}

Produk penelitian yang dihasilkan dalam penelitian ini meliputi modul pencegahan penyalahgunaan narkoba di sekolah untuk siswa beserta panduan penggunaannya untuk guru BK atau konselor. Keduanya menjadi satu kesatuan yang utuh dan tidak terpisahkan dalam tesis ini. Produk ini diberi nama Modul Bimbingan dan Konseling untuk Pencegahan Penyalahgunaan Narkoba di Sekolah. Dalam pengembangan produk ini, penulis mempedomani langkah-langkah yang tertuang dalam ADDIE model, yaitu analysis, design, development, implementation, dan evaluation. Dari hasil yang disajikan dalam tahap development diketahui bahwa modul yang disusun telah mencapai kriteria sangat layak secara isi/konstruk oleh para ahli. Hal ini dibuktikan dengan nilai rata-rata keseluruhan produk sebesar 87,72\% dan berada dalam kategori sangat layak.

Nilai kelayakan yang diberikan oleh para ahli tersebut merupakan nilai yang didasari oleh objektifitas terhadap isi/kandungan yang tertuang dalam modul. Objektifitas tersebut dapat dibuktikan dengan melihat hasil pengujian secara statistik dengan menggunakan Uji Signifikansi Koefisien Konkordansi Kendall. Dari hasil pengujian tersebut diketahui bahwa tingkat keselarasan penilaian yang diberikan mengindikasikan hubungan yang kuat antar ahli, yaitu nilai W sebesar 0,548.

Aspek tampilan/daya tarik dari modul yang disusun menarik. Artinya, tampilan dari modul yang dikembangkan tersebut dapat menarik minat siswa untuk membahas materi di dalamnya. Hal ini sesuai dengan pendapat Dimyati (1999: 30) bahwa isi pelajaran dalam bentuk warna, suara, gerak dan bentuk dapat membangkitkan perhatian siswa. Selanjutnya untuk aspek langkah-langkah pelaksanaan modul yang dikembangkan dapat dioperasionalkan oleh guru BK atau konselor. Guru BK atau konselor dapat memanfaatkan modul yang dikembangkan. Selanjutnya materi modul yang dikembangkan mudah dipahami baik oleh guru BK atau konselor, maupun siswa SMP. Dari aspek pemakaian bahasa sudah disesuaikan dengan kemampuan siswa SMP. Hal ini sesuai dengan karakteristik modul menurut Direktorat Pembinaan Sekolah Menengah Kejuruan (2008:4) yaitu modul hendaknya memenuhi kaidah user friendly atau bersahabat/ akrab dengan pemakainya. Setiap instruksi dan paparan informasi yang tampil bersifat membantu 
dan bersahabat dengan pemakainya, termasuk kemudahan dalam merespon dan mengakses sesuai dengan keinginan. Penggunaan bahasa yang sederhana, mudah dimengerti, serta menggunakan istilah yang umum digunakan, merupakan salah satu bentuk user friendly.

Di samping itu, penilaian yang diberikan oleh ahli terkait 5 aspek, yaitu tampilan/daya tarik, langkahlangkah pelaksanaan modul, peranan guru BK atau konselor, materi, dan pemakaian bahasa tidak ada yang menunjukkan penilaian yang di bawah standar kelayakan. Hal ini semakin menguatkan bahwa modul BK untuk pencegahan penyalahgunaan narkoba di sekolah layak secara isi/konstruk untuk dimanfaatkan.

Lebih jauh, modul yang telah divalidasi oleh para ahli semakin baik setelah mendapatkan penilaian dari guru BK atau konselor selaku pengguna. Argumentasi ini dapat dibuktikan dari persentase penilaian guru yaitu sebesar $87,53 \%$. Hal ini dapat dimaknai bahwa modul yang dikembangkan telah memperlihatkan hasil yang sangat baik untuk dapat diterima dan dimanfaatkan oleh guru BK atau konselor. Dengan demikian keseluruhan bagian produk penelitian yang dinilai telah dinyatakan baik dan sesuai untuk digunakan di sekolah.

Dari uraian tersebut terlihat bahwa modul pencegahan penyalahgunaan narkoba dapat digunakan, terutama pada tingkat SMP. Mengingat tingkat peredaran dan pemakaian narkoba semakin tinggi dari hari ke hari dan telah merambah dunia pendidikan, perlu dilakukan tindakan preventif oleh guru BK atau konselor. Guru BK atau konselor harus mampu memberikan pemahaman dan pengetahuan kepada siswa tentang bahaya penyalahgunaan narkoba, salah satunya dengan modul yang peneliti kembangkan.

\section{Tingkat keterpakaian Modul BK untuk Pencegahan Penyalahgunaan Narkoba di Sekolah}

Temuan penelitian dalam rangka mengetahui tingkat keterpakaian produk menggambarkan bahwa modul BK untuk pencegahan penyalahgunaan narkoba di sekolah tingkat keterpakaiannya tinggi oleh guru BK atau konselor dalam memberikan layanan.

Kenyataan yang dipaparkan di atas didukung oleh persentase keterpakaian produk, yaitu sebesar 87,53\% untuk skor rata-rata keseluruhan dan berada pada kategori sangat tinggi. Hal ini dapat dimaknai bahwa guru BK atau konselor mampu mempraktikkan produk. Di samping itu berdasarkan hasil pengujian secara statistik dengan menggunakan uji singnifikansi koefesien Kendalls (W) diketahui bahwa nilai W hitung sebesar 0,636. Hal ini dapat dimaknai bahwa tingkat kecocokan/keselarasan penilaian yang diberikan mengindikasikan hubungan yang tinggi antar guru BK atau konselor. Lebih jauh, penilaian yang diberikan oleh guru BK atau konselor terkait 3 (tiga) aspek, yaitu perencanaan, pelaksanaan, dan evaluasi tidak ada yang menunjukkan penilaian yang di bawah standar keterpakaian.

Secara umum, modul BK untuk pencegahan penyalahgunaan narkoba di sekolah yang disusun telah mencapai taraf keterpakaian yang memadai. Untuk aspek perencanaan dapat dilakukan oleh guru BK atau konselor dengan baik. Segala alat yang dibutuhkan untuk penggunaan modul dapat disediakan oleh guru BK atau konselor. Selanjutnya aspek pelaksanaan menunjukkan bahwa guru BK atau konselor dapat mengikuti langkah-langkah yang telah disusun. Berikutnya aspek evaluasi yang digunakan sudah mampu melihat perolehan siswa setelah mengikuti layanan. Hal tersebut relevan dengan pendapat Dharma (2008:3) yang menyatakan bahwa modul sebagai alat atau sarana pembelajaran yang berisi materi, metode, batasan-batasan, dan cara mengevaluasi yang dirancang secara sistematis dan menarik untuk mencapai kompetensi yang diharapkan sesuai dengan tingkat kompleksitasnya. Penggunaan modul ini juga akan mengarahkan siswa untuk menemukan konsep sendiri sehingga layanan dengan menggunakan modul akan lebih terfokus pada siswa sedangkan guru BK atau konselor hanya berfungsi sebagai fasilisator. Hal ini sesuai dengan pendapat Suryosubroto (1983: 2) bahwa dengan menggunakan modul siswa dapat belajar dengan kecepatan masingmasing dan lebih banyak belajar mandiri.

Dengan demikian produk penelitian berupa modul BK untuk pencegahan penyalahgunaan narkoba di sekolah secara praktik dapat dilakukan oleh guru BK atau konselor di sekolah.

\section{Keterbatasan Pengembangan}

Adapun keterbatasan pengembangan ini diuraikan sebagai berikut.

a. Responden dalam penelitian ini, yaitu guru BK atau konselor dengan jumlah dan cakupan yang masih terbatas pada 3 sekolah, yaitu 1 SMP negeri dan 2 SMP swasta.

b. Pengembangan produk dalam penelitian hanya sampai pada aspek keterpakaian, yaitu hanya melihat tingkat kemampuan guru BK atau konselor dalam memandu siswa menggunakan modul yang dikembangkan. 
c. Penelitian ini belum menjangkau dan mendalami aspek efektifitas dan kontribusi yang dapat diberikan untuk pencegahan penyalahgunaan narkoba di sekolah.

d. Pengkajian aspek keterpakaian produk dalam penelitian ini hanya diujicobakan pada satu jenis sekolah, yaitu sekolah umum.

e. Fokus pengembangan produk dalam penelitian ini hanya sebatas pencegahan, belum bisa digunakan untuk pengentasan masalah penyalahgunaan narkoba.

Harapan peneliti untuk peneliti lanjutan agar penelitian ini dapat ditindaklanjuti dengan melakukan eksperimen pada uji coba lapangan untuk melihat efektifitas dan kontribusi yang dapat diberikan untuk pencegahan penyalahgunaan narkoba di sekolah, sehingga produk penelitian yang dihasilkan dapat digunakan oleh guru BK atau konselor di SMP. Terkait dengan segala keterbatasan pengembangan ini semoga produk penelitian yang dihasilkan berguna dan bermanfaat bagi siswa dan perkembangan pendidikan ke depannya.

\section{SIMPULAN DAN SARAN}

Berdasarkan hasil pengembangan, maka dapat ditarik beberapa kesimpulan sebagai berikut:

1. Modul bimbingan dan konseling untuk pencegahan penyalahgunaan narkoba di sekolah secara isi dinilai layak untuk dimanfaatkan oleh guru bimbingan konseling dalam memberikan layanan kepada siswa untuk pencegahan penyalahgunaan narkoba.

2. Tingkat keterpakaian modul bimbingan dan konseling untuk pencegahan penyalahgunaan narkoba di sekolah dinilai tinggi untuk dapat digunakan sebagai media dalam layanan konseling.

Dengan demikian secara umum dapat disimpulkan bahwa rumusan modul bimbingan dan konseling untuk pencegahan penyalahgunaan narkoba di sekolah yang dihasilkan dinyatakan layak secara isi dan dapat dimanfaatkan oleh guru BK atau konselor untuk membantu siswa tercegah dari penyalahgunaan narkoba.

\section{Pemanfaatan Produk}

Beberapa hal yang perlu disarankan untuk pemanfaatan produk penelitian ini adalah sebagai berikut:

a. Produk yang dihasilkan yaitu modul bimbingan dan konseling untuk pencegahan penyalahgunaan narkoba di sekolah bukan satu-satunya alat/strategi untuk membantu siswa dalam rangka pencegahan penyalahgunaan narkoba di sekolah. Untuk itu perlu sinergi dengan pendekatan lainnya untuk mencapai hasil yang maksimal.

b. Guru BK atau konselor diharapkan dalam menggunakan produk ini memperhatikan kebutuhan dan karakteristik siswa yang tertuang dalam produk.

c. Dalam praktiknya, produk penelitian ini akan dapat terlaksana dengan baik apabila guru BK atau konselor memiliki kelengkapan alat pendukung. Untuk itu guru BK atau konselor diharapkan selalu melengkapi dan melakukan perencanaan yang matang sebelum memberikan layanan.

\section{Pengembangan Produk Lebih Lanjut}

Beberapa hal yang perlu disarankan untuk pengembangan produk lebih lanjut dalam penelitian ini adalah sebagai berikut:

a. Modul yang dikembangkan ini berupa prototype yang khusus untuk diimplementasikan pada siswa SMP. Penggunaan modul untuk selain siswa SMP diperlukan perumusan yang tepat sesuai dengan karakteristik siswa tersebut.

b. Prototype modul yang dikembangkan hanya sebatas pada uji coba kelompok kecil, untuk itu perlu dilakukan uji coba lapangan untuk melihat efektifitas pemakaian modul untuk pencegahan penyalahgunaan narkoba di sekolah.

\section{DAFTAR RUJUKAN}

Ahmad, Jamaludin. (2007). Modul dan Kaunseling Penyalahgunaan Dadah. Serdang: Universiti Putra Malaysia.

Ali. (2012). "Peredaran Narkoba di Kalangan Pelajar Mengkhawatirkan". (Online), (http://antarabogor.com, diakses 30 Juni 2012). 
Aziz, Deden Abdul. (2012). "Kasus Narkoba, Siswa SMP Ini Ujian di Tahanan”. (Online), (www.tempo.co, diakses 23 April 2012).

BSNP. (2006). Panduan Pengembangan Diri. Jakarta: Pusat Kurikulum.

Dharma, Surya. (2008). Penulisan Modul, Kompetensi Penelitian dan Pengembangan. Jakarta: Departemen Pendidikan Nasional.

Dimyati dan Mudjiono. (1999). Belajar Dan Pembelajaran. Jakarta: Rineka Cipta.

Direktorat Pembinaan Sekolah Menengah Kejuruan. (2008). Teknik Penyusunan Modul. Jakarta: Depdiknas.

Heriyani, Eka. (2009). Meningkatkan Pemahaman dan Sikap Terhadap Bahaya Penyalahgunaan Napza Melalui Layanan Bimbingan Kelompok (Studi Eksperimen Pada Siswa SMA N 12 Padang). Tesis tidak diterbitkan. Padang: Program Pascasarjana UNP.

Martinus, Yaspen. (2012). "Terpaksa Ikut UN di Bui karena Kasus Narkoba”. (Online), (www.tribunnews.com, diakses 12 April 2012).

Martono, Lydia Harlina dan Satya Joewana. (2006). Pencegahan dan Penanggulangan Penyalahgunaan Narkoba Berbasis Sekolah. Jakarta: Balai Pustaka.

Mulyasa, E. (2004). Kuriktilum Berbasis Kompetensi: Konsep, Karakteristik dan Implementasi. Bandung: Remaja Rosdakarya.

Nasution, MA. (1988). Berbagai Pendekatan dalam Proses Belajar Mengajar. Jakarta : Bina Aksara.

Prayitno. (2009). Wawasan Profesional Konseling. Padang: UNP

Santyasa, I Wayan. (2009). "Metode Penelitian Pengembangan dan Teori Pengembangan Modul”. Makalah disajikan dalam Pelatihan Bagi Para Guru TK, SD, SMP, SMA, dan SMK di Kecamatan Nusa Peninda Kabupaten Klungkung, Pusat Penelitian Universitas Pendidikan Ganesha, Klungkung, 12-14 Januari.

Siegel, Sydney. (1997). Statistic Nonparametrik untuk Ilmu-Ilmu Sosial. Jakarta: Gramedia Pustaka Utama.

Sugiyono. (2010). Metode Penelitian Kuantitatif, Kualitatif dan R \& D. Bandung: Alfabeta.

Suryosubroto. (1983). Sistem Pembelajaran Dengan Modul. Yogyakarta: PT. Bina Aksara.

Undang-Undang Republik Indonesia Nomor 20 tahun 2003 tentang Sistem Pendidikan Nasional. Jakarta: Sekretariat Jenderal Departemen Pendidikan Nasional.

Yusuf, A Muri. (2005a). Dasar-Dasar dan Teknik Evaluasi Pendidikan. Padang: UNP Press. (2005b). Metodologi Penelitian: Dasar-Dasar Penyelidikan Ilmiah. Padang: UNP Press. 